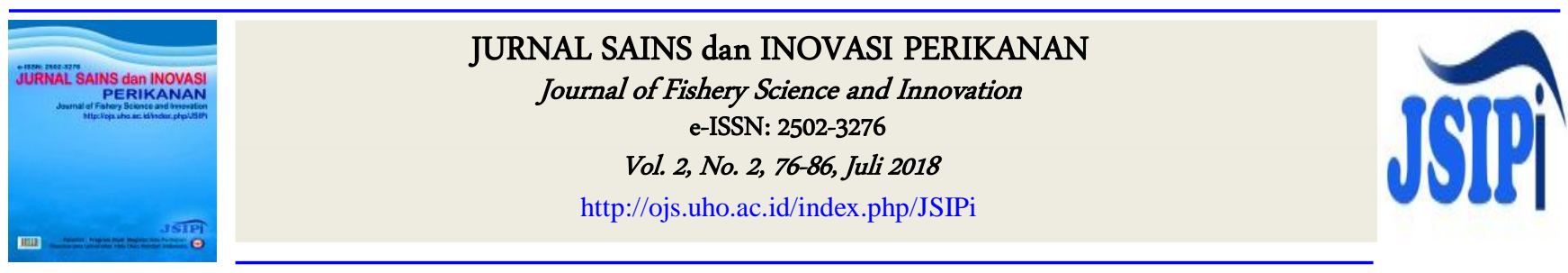

\title{
Kajian Tingkat Efektivitas Pengelolaan Daerah Perlindungan Laut Berbasis Masyarakat Desa Waha Kabupaten Wakatobi Indonesia
}

\author{
Study on Efficacy of Community Based Management \\ of Marine Protected Area at Waha Village of Wakatobi Regency Indonesia
}

\author{
Ishak Iskandar ${ }^{\left.1{ }^{*}\right)}$, Andi Irwan Nur ${ }^{2)}$, Baru Sadarun ${ }^{2)}$ \\ 1) Fakultas Perikanan dan Ilmu Kelautan, Universitas Halu Oleo Kendari, Indonesia \\ Corresponding author $\left.{ }^{*}\right)$ : andhar_79@yahoo.co.id
}

\begin{abstract}
Marine Protected Areas (MPAs) are a common management approach that applied to protect and conserve coastal and marine resources in the world. However, in some areas where these approach have been implemented, the goals and targets did not proceed as expected and resulted in methods and objects of study that are relatively irrelevant to the existing conditions. Therefore, a review and more efforts are required to determine the efficacy of the MPAs management. The community based management of marine protected area at Waha Village can be regarded as a manifestation of the local people to meet their needs by utilizing natural resources sustainably. Therefore, this study aims to asses the ecological and socio-economic condition as well as community institutions to determine whether the community based management of the MPA is effective. Ecological data collection was divided into several indicators such as coral reef, seagrass and coral fish community condition that was collected through direct survey using SCUBA. Whereas socio-economic and institutional data was obtained in three stages include observation, semi-structured interviews and surveys. The percentage of live coral cover on MPA of Waha Village was 55,83\%. There were 28 species from 9 families and 14 genuses of target fish found in MPA of Waha Village. Seagrass density was 299.87 stands $/ \mathrm{m}^{2}$ with average value of seagrass presentation was $63,25 \%$, indicating that seagrass is in good condition. Based on the effectiveness analysis using the Amoeba technique, the indicator values were generally better in performance than the critical threshold value (CTV) indicator. This is because these values have not passed the CTV. The degree of effectiveness of community based management of MPA at Waha Village was 79,17\%, suggesting that these management approach is very effective to conserve marine natural resources in the area.
\end{abstract}

Keywords : Effectiveness, management, protected area.

\begin{abstract}
ABSTRAK
Daerah Perlindungan Laut (DPL) merupakan pendekatan yang umum diterapkan pada program pengelolaan sumberdaya pesisir dan laut di dunia. Beberapa daerah yang telah dikonservasi, tujuan dan sasarannya tidak berjalan seperti yang diharapkan dan menghasilkan metode dan objek studi yang relatif tidak relevan dengan kondisi yang ada, dengan demikian diperlukan tinjauan dan memahami sejauh mana upaya pengelolaan DPL berjalan secara efektif. DPL Desa Waha dapat dianggap sebagai manifestasi dari keinginan masyarakat untuk memenuhi kebutuhannya, seperti kebutuhan untuk menikmati, memanfaatkan sumberdaya alam secara lestari. Secara umum tujuan penelitian ini adalah mengkaji kondisi ekologi perairan, kondisi sosial ekonomi dan kelembagaan masyarakat dan mengetahui tingkat efektivitas pengelolaan DPL. Pengambilan data ekologi terbagi atas beberapa indikator diantaranya kondisi terumbu karang, kondisi lamun dan kondisi ikan karang. Metode pengumpulan data sosial-ekonomi dan kelembagaan dilakukan beberapa tahap yakni observasi, semistruktur wawancara dan survei. Berdasarkan hasil pengamatan, persentase tutupan karang keras hidup pada DPL Desa Waha adalah sebanyak 55,83\%. Tercatat ada 28 spesies dari 9 famili dan 14 genus ikan target yang terdapat di DPL Desa Waha. Hasil analisis data kerapatan lamun DPL Desa Waha, menunjukan nilai rata-rata
\end{abstract}


kerapatan yaitu 299,87 tegakan/m² dengan nilai rata-rata presentasi lamun yaitu 63,25\%, termaksud dalam kategori baik. Berdasarkan analisis efektivitas menggunakan teknik Amoeba, nilai-nilai indikator secara umum terlihat keragaan (performance) indikator lebih baik dibandingkan dengan indikator nilai ambang batas kritis (CTV). Hal ini dikarenakan nilai-nilai tersebut belum melewati nilai CTV. Berdasarkan hasil perhitungan tingkat efektivitas pengelolaan DPL Desa Waha berada pada tingkat 77,52\% dan dikategorikan efektif.

Kata kunci: efektivitas, pengelolaan, perlindungan laut

\section{DOI: http://dx.doi.org/10.33772/jspi.v3n1.}

\section{PENDAHULUAN}

Perairan di Kepulauan Wakatobi Indonesia memiliki keanekaragaman terumbu karang dan jenis biota laut khususnya ikan tertinggi di dunia (Supriatna, 2008). Perairan ini mempunyai 25 gugusan terumbu karang yang masih asli dengan terdapat 396 spesies beraneka ragam bentuk, dari 599 spesies karang dunia. Wakatobi juga sebagai Kawasan Taman Nasional Laut dengan luas 1.390.000 ha, ditetapkan sebagai taman nasional laut melalui Keputusan Menteri Kehutanan RI No. 393/KptsVI/1996. Keanekaragaman hayati laut, skala dan kondisi karang merupakan prioritas tertinggi dalam konservasi laut di Indonesia (Ayiful, 2004).

Daerah Perlindungan Laut Berbasis Masyarakat (DPL-BM) merupakan pendekatan yang umum diterapkan pada program pengelolaan sumberdaya pesisir dan laut di dunia, terutama di negara-negara berkembang yang memiliki ekosistem terumbu karang. Daerah perlindungan laut dapat dianggap sebagai manifestasi dari keinginan masyarakat untuk memenuhi kebutuhannya, seperti kebutuhan untuk menikmati, memanfaatkan sumberdaya alam secara lestari, kebutuhan untuk menikmati keindahan alam dan kebutuhan untuk melindungi hak sebagai pemilik sumberdaya dari pengguna luar (Faiza 2011).

Salah satu program yang mengadopsi konsep daerah perlindungan laut adalah Program COREMAP (Coral Reef Rehabilitation and Management Program) di Kabupaten Wakatobi. Tujuan program pengelolaan berbasis masyarakat COREMAP antara lain adalah pemberdayaan masyarakat pesisir agar mampu melestarikan terumbu karang dan ekosistem lainnya melalui pengelolaan bersama dengan pembentukan Daerah Perlindungan Laut.

Keberadaan daerah perlindungan laut dalam pelaksanaannya diharapkan tidak hanya memberikan manfaat bagi sisi ekologis tetapi juga berdampak pada perbaikan kondisi sosial dan ekonomi masyarakat. Mengingat pentingnya keberadaan daerah perlindungan laut, maka perlu melihat peluang keberlanjutannya, baik didasarkan pada indikator ekologis, sosial ekonomi maupun tata kelola.

Permasalahannya bahwa dari sejumlah DPL pembentukan program COREMAP khususnya yang ada di Kabupaten Wakatobi telah banyak yang terbengkalai dan tidak terjaga keberlangsungannya, yang salah satu sebabnya karena kurangnya kesadaran masyarakat di sekitar DPL dengan tetap melakukan kegiatan perikanan di kawasan DPL. Namun, salah satu DPL yang terbilang masih berjalan dan termanfaatkan adalah DPL Waha yang berada di Kecamatan Wangi-Wangi Kabupaten Wakatobi.

Berdasarkan uraian di atas maka dipandang perlu untuk melakukan penelitian mengenai Tingkat Efektivitas Pengelolaan DPL dengan harapan agar kelebihan dan kekurangan dalam pengelolaannya dapat menjadi bahan pembelajaran bagi peningkatan kualitas pengelolaan DPL-BM khususnya di Desa Waha Kabupaten Wakatobi.

Secara umum tujuan penelitian adalah mengkaji kondisi ekologi perairan DPL Desa Waha Kabupaten Wakatobi; kondisi sosial ekonomi dan kelembagaan masyarakat sekitar DPL; serta mengetahui tingkat efektivitas pengelolaan DPL

\section{METODE PENELITIAN}

Penelitian ini dilakukan di Desa Waha Kabupaten Wakatobi selama 3 bulan dari Maret hingga Mei 2018. Lokasi penelitian dapat dilihat pada Gambar 1.

Metode penentuan stasiun pengambilan sampel dilakukan dengan cara purposive random sampling yaitu penentuan stasiun dengan menggunakan faktor ekologi dan pendekatan masyarakat sebagai pertimbangan utama.

Pengambilan data ekologi terbagi atas beberapa indikator diantaranya kondisi karang, kondisi ikan karang dan kondisi lamun.

\section{Pengamatan Karang}


78 Ishak Iskandar et al.

JURNAL SAINS dan INOVASI PERIKANAN / Journal of Fishery Science and Innovation

Vol. 2, No. 2, 76-86, Juli 2018

Pengamatan dilakukan dengan metode transek garis yakni dengan metode Point Intercept Transect (PIT) sepanjang 50 meter yang diletakan pada kedalaman 6-10 meter dan sejajar dengan garis pantai. Transek dibuat dengan menggunakan roll meter. Jenis karang yang berada di bawah garis transek dicatat dengan ketelitian setiap 0,5 meter. Pengamatan dilakukan dengan menggunakan SCUBA dengan melakukan 2 kali ulangan untuk mendapatkan keakuratan data yang peroleh. (Manuputty dan Djuwariah, 2009).

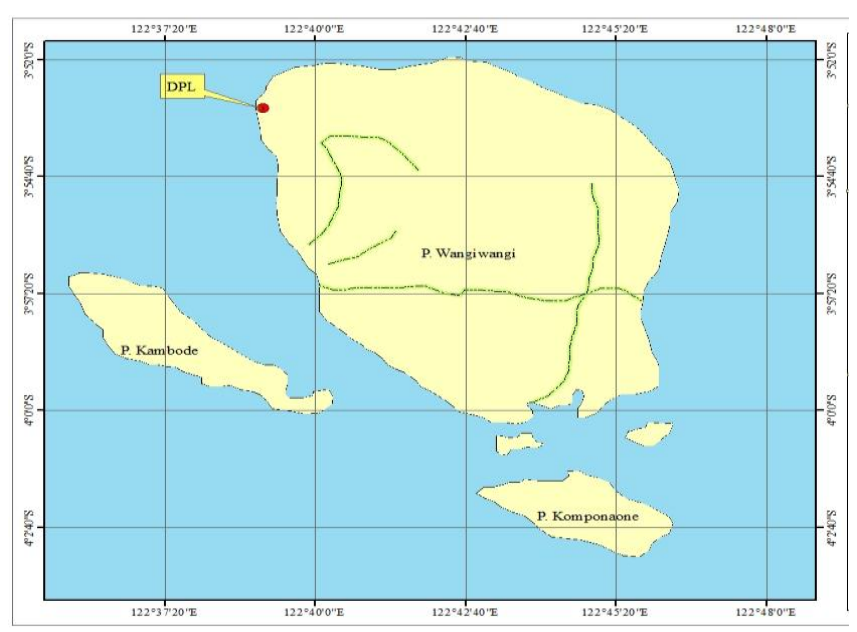

Gambar 1. Peta lokasi penelitian Desa Waha Kabupaten Wakatobi Sulawesi Tenggara Indonesia

\section{Pengamatan Ikan Karang}

Metode yang digunakan dalam penelitian ikan karang adalah visual sensus dan transek garis. Pengamatan dilakukan dengan menggunakan peralatan (SCUBA). Transek sepanjang 50 meter dibuat sejajar dengan garis pantai, dengan jarak pengamatan 2,5 meter kiri dan kanan garis transek. Transek garis dibuat pada kedalaman 6-10 meter. Jenis ikan yang dicatat dibedakan atas 3 kelompok besar yaitu, spesies indikator, spesies target dan ikanikan lainnya (mayor group).

\section{Pengamatan Lamun}

Metode yang digunakan untuk pengambilan data kondisi lamun adalah transek kuadrat (tegak lurus garis pantai). Metode transek kuadrat terdiri dari transek dan frame berbentuk kuadrat. Transek adalah garis lurus yang ditarik di atas padang lamun, sedangkan kuadrat adalah bingkai berbentuk segi empat sama sisi yang diletakkan pada garis tersebut (Pusat Penelitian Oseanografi-LIPI, 2014). Pengambilan data dilakukan pada tiga transek dengan panjang masing-masing $100 \mathrm{~m}$ dan jarak antara transek adalah $50 \mathrm{~m}$. Frame kuadrat diletakkan disisi kanan transek dengan jarak antara kuadrat satu dengan yang lainnya adalah $10 \mathrm{~m}$. Titik awal transek diletakkan pada jarak 5-10 m dari kali pertama lamun dijumpai. Prosedur pengambilan data adalah : Menentukan titik pengamatan; Membuat transek dengan menarik roll meter sepanjang 100 meter ke arah tubir; Menempatkan kuadrat $50 \times 50 \mathrm{~cm}^{2}$ pada titik $0 \mathrm{~m}$, disebelah kanan transek; Menentukan komposisi jenis lamun dan nilai persentase tutupan lamun pada setiap kotak kecil dalam frame kuadrat.

\section{Metode Pengambilan Data Sosial Ekonomi dan Kelembagaan}

Metode pengumpulan data sosial-ekonomi dan kelembagaan dilakukan beberapa tahap yakni observasi, semi-struktur wawancara dan survei (Pollnac et al. 2000).

\section{Analisis Kondisi karang}

Kecenderungan dari kualitas terumbu karang sejak adanya program DPL ini, dinilai apakah kualitas karang mengalami penurunan, tetap atau sebaliknya mengalami peningkatan yaitu dengan membandingkan kondisi awal tutupan karang sejak awal ditetapkan program DPL, dengan kondisi saat ini berdasarkan metode panduan PIT (Manupatty dan Djuwariah 2009) sebagai berikut:

$$
\mathrm{C}=\sum_{i=1}^{n}\left[\frac{N i}{N}\right] \mathrm{X} 100 \%
$$

Keterangan :

$\mathrm{C}=$ Persen tutupan karang

$\mathrm{Ni}=$ Jumlah tiap komponen

$\mathrm{N}=$ Total komponen

Kriteria persentase penutupan karang hidup berdasarkan Gomez dan Yap (1988) adalah kriteria buruk dengan kisaran $0.0 \%$ - 24.9\%; kriteria sedang pada kisaran 25\% - 49.9\%; kriteria baik dengan kisaran $50 \%-74.9 \%$; dan kriteria sangat baik dengan kisaran $75 \%-100 \%$.

\section{Kelimpahan Sumberdaya Ikan Karang}

Keberadaan ikan-ikan ini akan dilihat dari segi kelimpahan dan kondisi awal saat ditetapkan sebagai DPL di bandingkan dengan kondisi saat ini. Kelimpahan ikan di hitung dengan rumus menurut Brower et al .(1990) sebagai berikut:

$$
\mathrm{Ni}=\frac{\sum_{j=1}^{p} n i j}{A}
$$


JURNAL SAINS dan INOVASI PERIKANAN / Journal of Fishery Science and Innovation Vol. 2, No. 2, 76-86, Juli 2018

Keterangan :

$\mathrm{Ni}=$ Kelimpahan ikan (induvidu $/ \mathrm{m}^{2}$ )

$n_{i j}=$ Jumlah total individu dari spesies ke $-\mathrm{i}$

$A=$ Luas total daerah pengambilan contoh $\left(\mathrm{m}^{2}\right)$

Penentuan kriteria kelimpahan ikan karang di Daerah Perlindungan Laut (DPL) menurut COREMAP II didasarkan pada kelimpahan ikan karang kelompok Ikan Target (Manuputty dan Djuwariah 2009). Kelompok Ikan Target dapat dikategorikan sebagai berikut:

- "Sedikit" = individu Ikan Target sepanjang transek $<25$ ekor;

- "Sedang" = individu Ikan Target sepanjang transek > 25-50 ekor;

- "Banyak" = individu Ikan Target sepanjang transek > 50 ekor.

\section{Kondisi Tutupan Lamun}

Peniliaian kondisi tutupan lamun sejak mulainya program DPL sampai sekarang, apakah kualitas lamun mengalami penurunan, tetap atau sebaliknya mengalami peningkatan yaitu dengan membandingkan kondisi tutupan lamun sejak awal di tetapkan program DPL, dengan kondisi saat ini. Cara menghitung penutupan lamun dalam satu kuadrat adalah menjumlah nilai penutupan lamun pada setiap kotak kecil dalam kuadrat dan membaginya dengan jumlah kotak kecil, yaitu empat (Pusat Penelitian Oceanograpi-LIPI, 2014) :

Jumlah penutupan lamun seluruh transek Jumlah kuadrat seluruh transek

\section{Analisis Data Sosial Ekonomi dan Kelembagaan}

Analisis ini digunakan untuk memaparkan data yang relevan terhadap keefektifan Daerah Perlindungan Laut yang telah diterapkan. Data dianalisis dengan perhitungan sederhana, yakni perhitungan dalam bentuk indeks, total penjumlahan dan persentase dari beberapa indikator yang ada. Hasil dari perhitungan ini digambarkan dalam bentuk grafik yakni pie charts, tabel, dan diagram. Perbandingan juga dilakukan pada beberapa indikator untuk melihat perbedaan terhadap pemanfaatan dan pengelolaan DPL yang terjadi dalam beberapa tahun terakhir. Data kuantitatif ini juga dibandingkan dengan data sekunder yang dikumpulkan dari instansi-instansi terkait untuk mendapatkan data yang lebih akurat dan mencegah adanya bias data (Pollnac et al. 2000).

\section{Metode Likert's Summeted Rating}

Pendekatan ini dilakukan untuk mengetahui persepsi, sikap dan partisipasi masyarakat terhadap keberadaan program DPL.

\section{Analisis Tingkat Efektivitas DPL}

Penentuan indikator efektivitas dalam evaluasi pengelolaan DPL Desa Waha merupakan indikator yang ada pada International Union for Conservation of Nature (IUCN) dalam Pomeroy et al. (2004) yang ditawarkan kepada stakeholder. Untuk menentukan indikator efektivitas terlebih dahulu dilakukan tahap analisis stakeholder (Grimble dan Chan 1995), dalam hal ini penentuan stakeholder yang memiliki kepentingan dan berpengaruh dalam memutuskan.

Efektivitas (degree of efectiveness) DPL Desa Waha dinilai berdasarkan setiap tingkat (indeks) dari indikator-indikator terpilih. Tingkatan tersebut disusun dari 0 hingga 3 dan ditetapkan tingkat efektivitasnya menggunakan kelas persentase $0-100 \%$ yang menunjukkan tingkatan tidak efektif hingga sangat efektif. Pembobotan masing-masing indikator ditetapkan berdasarkan analisis stakeholder dengan total nilai bobot adalah 100 menggunakan rumus sebagai berikut (Carter et al. 2011):

$$
\mathrm{C}=\sum_{i=1}^{n}\left[\frac{S c i}{S c}\right] \times 100 \%
$$

Keterangan:

$\mathrm{C}=$ Bobot indikator

Sci $=$ Skor indikator $\mathrm{i}$

$\mathrm{Sc}=$ Skor total dari seluruh indikator

Berdasarkan perhitungan tersebut, didapatkan tingkat (indeks) efektivitas pengelolaan DPL sebagai berikut :

$$
\begin{array}{lll}
<25 \% & : & \text { sangat tidak efektif } \\
25-50 \%: & \text { tidak efektif } \\
50-75 \%: & \text { efektif } \\
75-100 \%: & \text { sangat efektif }
\end{array}
$$

\section{HASIL DAN PEMBAHASAN}

DPL Desa Waha memiliki karakteristik pesisir terdiri dari vegetasi pohon kelapa dengan pantai yang berpasir putih. Dari data Dinas Kelautan dan Perikanan Kabupaten Wakatobi luasan DPL Desa Waha yaitu panjang 577,75 meter dan lebar 325,09 meter atau seluas 18,78 Ha. Koordinat pembatas DPL Desa Waha pada Tabel 1. 
80 Ishak Iskandar et al.

JURNAL SAINS dan INOVASI PERIKANAN / Journal of Fishery Science and Innovation

Vol. 2, No. 2, 76-86, Juli 2018

\section{Pemanfaatan Sumberdaya Laut}

Penangkapan ikan merupakan kegiatan utama warga yang berada di sekitar perairan waha sanpai lepas pantai. Hasil tangkapan tidak saja untuk dikonsumsi tetapi juga dijual kepada pengumpul yang ada di pulau atau kepada industri yang ada di wilayah Wakatobi.

Tabel 1. Titik koordinat masing-masing pelampung DPL Desa Waha

\begin{tabular}{cccc}
\hline \multirow{2}{*}{$\begin{array}{c}\text { Titik } \\
\text { Pelampung }\end{array}$} & \multicolumn{2}{c}{ Posisi } & \multirow{2}{\text{Luas}}{$\begin{array}{c}\text { LS } \\
\text { (ha) }\end{array}$} \\
\cline { 2 - 3 } & 5.24833 & 123.52700 & 18,78 \\
2 & 5.25147 & 123.52285 & \\
3 & 5.25353 & 123.52512 & \\
4 & 5.25017 & 123.52928 & \\
\hline
\end{tabular}

Dalam rangka pemanfaatan dan pengelolaan kawasan konservasi, DPL di Desa Waha pada Tahun 2011 mulai dikembangkan menjadi kegiatan ekowisata berbasis masyarakat desa berupa lembaga Waha Tourism Community (WTC). Sebelumnya, terdapat Nota Kesepakatan antara Ketua LPSTK Desa Waha dan Manajer WTC pada tanggal 10 November 2010 yang berisi antara lain bahwa LPSTK memiliki wewenang melakukan supervise terhadap pelaksanaan kegiatan WTC. Kepengurusan lembaga WTC disahkan melalui Keputusan Kepala Desa Nomor 03/WTC/2012 tanggal 7 Januari 2012. Dalam perkembangannya peran WTC sebagai lembaga pengelola DPL Waha menjadi lebih dominan.

Mengadopsi sistem kerja LPSTK, WTC melakukan aktivitas dengan membentuk beberapa kelompok masyarakat yang bergerak di bidang taman biota laut, pemandu pariwisata dan makanan tradisional. Lembaga WTC sebagai pengelola DPL Desa Waha saat ini dilaksanakan oleh warga asli Desa Waha yang terlibat aktif dalam pelaksanaan Coremap di Desa Waha sejak awal program ini dilaksanakan di Desa Waha. Secara pribadi pengelola telah mengikuti berbagai program peningkatan kapasitas berupa berbagai pelatihan dan workshop pengelolaan terumbu karang. Dari pengalaman sebagai pelaku pengelola pelestarian terumbu karang dan aktivitas peningkatan kapasitas dalam bidang konservasi, pengelola WTC memiliki kemampuan dalam melakukan pengelolaan DPL berbasis masyarakat di Desa Waha. Pengelola WTC cukup mampu mengkoordinasikan pelayanan bagi aktivitas wisata di
DPL Waha dan turun langsung sebagai pemandu wisata.

\section{Evaluasi Kualitas Ekologi DPL}

Penyebaran karang di Desa Waha cukup luas sepanjang pesisir Desa Waha. Berdasarkan hasil pengambilan data tiga titik pengamatan di DPL Desa Waha menunjukan bahwa presentase tutupan karang keras hidup (HC) tergolong kategori sedang sampai baik. Dalam hal ini tingkat kerusakan sangat sedikit dan penyebab kerusakan diakibatkan oleh faktor alam. Data hasil pengamatan rata-rata persentase tutupan karang di DPL Desa Waha pada Tabel 2.

Tabel 2. Rata-rata persentase tutupan karang di DPL Desa Waha

\begin{tabular}{|c|c|}
\hline Kategori biota & Rata-rata Tutupan \\
\hline Hard Coral (Karang Hidup) : & $55,83 \%$ \\
\hline - Acropora & $14,10 \%$ \\
\hline - Non Acropora & $3 \%$ \\
\hline Dead Coral (Karang Mati): & $9,33 \%$ \\
\hline - Dead Coral & $4,50 \%$ \\
\hline $\begin{array}{l}\text { - Dead Coral with } \\
\text { Algae }\end{array}$ & $4,83 \%$ \\
\hline Other Fauna: & $13,00 \%$ \\
\hline - Soft Coral & $3,67 \%$ \\
\hline - Sponge & $3,50 \%$ \\
\hline - Others & $5,83 \%$ \\
\hline Algae & $4,17 \%$ \\
\hline Abiotic: & $17,67 \%$ \\
\hline - Rubble & $9,00 \%$ \\
\hline - $\quad$ Sand & $8,67 \%$ \\
\hline
\end{tabular}

Berdasarkan hasil pengamatan selama penelitian ini persentase tutupan karang keras hidup pada DPL Desa Waha adalah sebanyak $55,83 \%$ yang didominasi oleh kelompok bentik Terumbu karang Non Acropora sebanyak $41,73 \%$ dan Acropora 14,10\%. Data peresentase tutupan karang setiap titik pengamatan pada Gambar 2.

Pengamatan kondisi karang difokuskan di DPL Desa Waha. Pada saat pengamatan kondisi perairan cukup jernih dimana kedalaman lokasi penelitian berkisar 5-13 meter dengan kekuatan arus relatif tinggi. Formasi yang terlihat pada komunitas terumbu karang, tersusun atas penutupan oleh beberapa komponen yakni karang hidup (hard coral), karang mati (deadt coral), other fauna, alga, dan komponen abiotik (patahan karang dan pasir). Berdasarkan hasil pengamatan didapatkan persentase tutupan karang 
hidup di DPL Desa Waha termasuk kategori "sedang sampai baik".

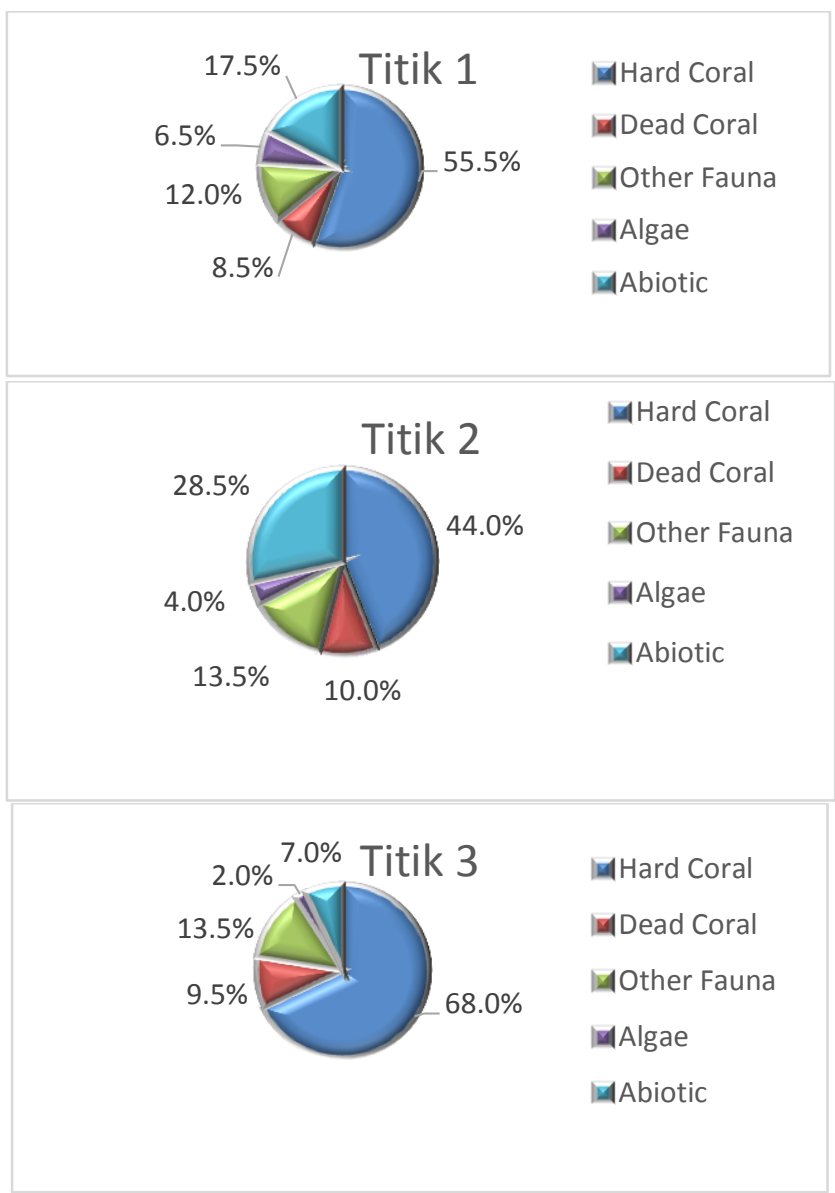

Gambar 2. Presentase tutupan karang

Data pengamatan pada titik 1 menunjukkan kondisi karang termaksud dalam ketegori baik dengan persentase karang hidup sebesar 55,5\% yang terdiri dari acropora sebesar 21,3\% dan non acropora sebesar $34,2 \%$, sedangkan yang lainnya yaitu karang mati sebesar $8,5 \%$, other fauna sebesar $12 \%$, algae sebesar $6,5 \%$, dan abiotic sebesar $17,5 \%$.

Data pengamatan pada titik 2 menunjukkan kondisi karang termaksud dalam ketegori sedang dengan persentase karang hidup sebesar $44 \%$ yang terdiri dari acropora sebesar $21,3 \%$ dan non acropora sebesar $34,2 \%$, sedangkan yang lainnya yaitu karang mati sebesar $13,5 \%$, other fauna sebesar $4 \%$, algae sebesar 28.5,5\%, dan abiotic sebesar $13,5 \%$.

Data pengamatan pada titik 3 menunjukkan kondisi karang termaksud dalam ketegori sedang dengan persentase karang hidup sebesar $68 \%$ yang terdiri dari acropora sebesar $21,3 \%$ dan non acropora sebesar $34,2 \%$, sedangkan yang lainnya yaitu karang mati sebesar $9,5 \%$, other fauna sebesar $13,5 \%$, algae sebesar $2 \%$, dan abiotic sebesar $7 \%$.

Hasil pengamatan tahunan mulai tahun 2006 sampai 2018 menunjukan persentase tutupan karang keras menunjukkan peningkatan dibanding awal pembentukan DPL, walau kemudian nilainya berfluktuasi tetapi secara rata-rata memperlihatkan kondisi yang lebih baik. Beberapa aspek yang menunjukan perkembangan positif sejak dibentuknya DPL di Desa Waha yaitu kegiatan eksploitasi karang dan penggunaan bom yang sudah tidak ditemukan lagi di DPL Desa Waha. Hal ini berdampak pada perkembangan tutupan karang hidup dan kelimpahan ikan cenderung semakin baik. Hasil monitoring dari DKP Wakatobi pada tahun 2006 (awal) pembentukan DPL Desa Waha tutupan karang hidup adalah sebesar 19\%, dan persentase tutupan karang hidup mulai meningkat pada tahun 2008-2017 (Alwin, 2017).

\section{Kelimpahan Ikan Karang}

Ikan karang merupakan sekumpulan ikan Selama penelitian jumlah total ikan karang yang berhasil disensus dari ketiga titik sebanyak 104 jenis yang mewakili 40 genus dan 20 famili (Lampiran 2). Jenisjenis ikan yang umum dijumpai terdiri dari suku Pomacanthidae (23 jenis), Chaetodontidae (13 jenis), Acanturidae (10 jenis), Pomacentridae (9 jenis), Labridae (3 jenis), Luthjanidae (6 jenis), Apogonidae (5 jenis), Cirrhitidae (5 jenis), Balistidae (4 jenis), Caesionidae (4 jenis), Siganidae (4 jenis), Scaridae (4 jenis), Carangidae (3 jenis), Serranidea (3 jenis), Spyraenidae (2 jenis), Nemipteridae (2 jenis), Mullidae (2 jenis), Epipididhae (1 jenis), Kyphosidae (1 jenis), Zanclidae (1 jenis). Jumlah spesies yang terdapat di DPL Desa Waha tergolong tinggi, hal ini mempengaruhi tingginya kelimpahan ikan karang pada Gambar 4.

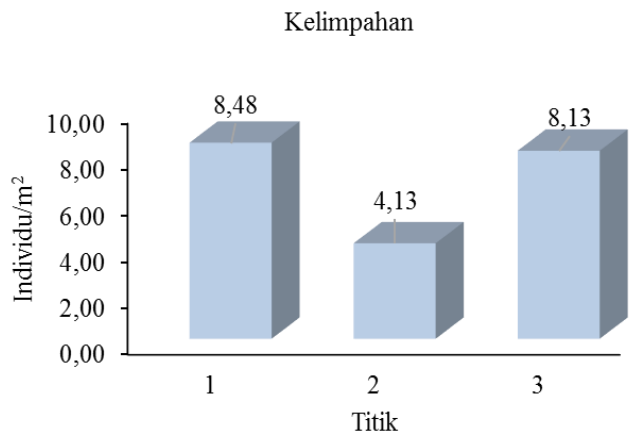

Gambar 3. Kelimpahan ikan karang 
82 Ishak Iskandar et al.

JURNAL SAINS dan INOVASI PERIKANAN / Journal of Fishery Science and Innovation

Vol. 2, No. 2, 76-86, Juli 2018

Berdasarkan data kelimpahahan ikan karang yang terdapat di 3 titik pengamatan menggambarkan nilai yang relative tinggi khususnya titik 1 dan titik 3 . Kelimpahan ikan pada titik 1 yaitu $8,48 \mathrm{ind} / \mathrm{m}^{2}$, titik 2 yaitu $4,13 \mathrm{ind} / \mathrm{m}^{2}$, dan titik 3 yaitu $8,13 \mathrm{ind} / \mathrm{m}^{2}$. Kelimpahan ikan terendah terdapat pada titik pengamatan 2, hal ini dipengaruhi oleh kondisi tutupan karang yang juga rendah dibandingkan dengan titik pengamatan lainnya. Hal ini sesuai dengan penelitian yang dilakukan oleh Ahmad (2013), di Pulau Samatellulompo yang menyimpulkan bahwa kelimpahan ikan tertinggi berada pada stasiun yang memiliki kondisi terumbu karang yang baik dibandingkan pada stasiun yang memiliki kondisi terumbu karang yang kurang baik. Dengan demikian, ketika presentase tutupan karang tinggi maka kelimpahan ikan akan tinggi pula, begitu pun sebaliknya.

Ikan target adalah ikan-ikan yang lebih dikenal oleh nelayan sebagai ikan konsumsi seperti famili Serranidae, Lutjanidae, Haemulidae, Lethrinidae, Caesionidae, Siganidae, Mullidae dan lain-lain. Hal ini sesuai dengan penelitian Balai Taman Nasional Baluran (2010) menyatakan ikan yang merupakan target penangkapan atau lebih dikenal juga dengan ikan ekonomis penting atau ikan komsumsi seperti Seranidae, Lutjanidae, Haemulidae, Lethrinidae, Caesionidae, Siganidae, Muldae, dan masih banyak lainnya. Selanjutnya Subhan (2009), menyatakan Ikan-ikan yang dimaksud dengan spesies target meliputi ikan-ikan konsumsi dan ekonomis penting yang berasosiasi dengan karang. Kelompok ikan target disajikan pada Tabel 3.

Tabel 3. Kelompok ikan target

\begin{tabular}{|c|c|c|c|}
\hline No & Famili & Genus & Spesies \\
\hline 1 & Caesionidae & Caesio & Caesio teres \\
\hline & & & Pterocaesio \\
\hline 2 & & Pterocaesio & $\begin{array}{l}\text { chrysozona } \\
\text { Pterocaesio }\end{array}$ \\
\hline 3 & & & tesselatus \\
\hline 4 & & & Pterocaesio tile \\
\hline 5 & Carangidae & Caran $x$ & Caranx bajad \\
\hline 6 & & & $\begin{array}{l}\text { Caranx ferdau } \\
\text { Caranx }\end{array}$ \\
\hline 7 & & & melampygus \\
\hline 8 & Epipididhae & Platax & $\begin{array}{l}\text { Platax teira } \\
\text { Cheilinus }\end{array}$ \\
\hline 9 & Labridae & Cheilinus & $\begin{array}{l}\text { diagramus } \\
\text { Cheilinus }\end{array}$ \\
\hline 10 & & & trilobatus \\
\hline
\end{tabular}

\begin{tabular}{|c|c|c|c|}
\hline No & Famili & Genus & Spesies \\
\hline 11 & & Thalasoma & $\begin{array}{l}\text { Thalasoma } \\
\text { lunare } \\
\text { Lutianus }\end{array}$ \\
\hline 12 & Luthjanidae & Lutjanus & biguttatus \\
\hline 13 & & & Lutjanus fulvus \\
\hline 14 & & & $\begin{array}{l}\text { Lutjanus gibbus } \\
\text { Lutjanus }\end{array}$ \\
\hline 15 & & & kasmira \\
\hline 16 & & & $\begin{array}{l}\text { Lutjanus ruselli } \\
\text { Paracaesio }\end{array}$ \\
\hline 17 & & Paracaesio & $\begin{array}{l}\text { xanthurus } \\
\text { Parupeneus }\end{array}$ \\
\hline 18 & Mullidae & Parupeneus & $\begin{array}{l}\text { barberinus } \\
\text { Parupeneus }\end{array}$ \\
\hline 19 & & & $\begin{array}{l}\text { multifasciatus } \\
\text { Anyperodon }\end{array}$ \\
\hline 20 & Serranidea & Anyperodon & $\begin{array}{l}\text { leucogrammicus } \\
\text { Cephalopholis }\end{array}$ \\
\hline 21 & & Cephalopholis & $\begin{array}{l}\text { miniata } \\
\text { Epinephelus }\end{array}$ \\
\hline 22 & & Epinephelus & $\begin{array}{l}\text { merra } \\
\text { Siganus }\end{array}$ \\
\hline 23 & Siganidae & Siganus & $\begin{array}{l}\text { corallinus } \\
\text { Siganus }\end{array}$ \\
\hline 24 & & & $\begin{array}{l}\text { fulpinus } \\
\text { Siganus }\end{array}$ \\
\hline 25 & & & guttatus \\
\hline 26 & & & $\begin{array}{l}\text { Siganus puellus } \\
\text { Spyraeni }\end{array}$ \\
\hline $\begin{array}{l}27 \\
28\end{array}$ & Spyraenidae & Spyraeni & $\begin{array}{l}\text { baracuda } \\
\text { Spyraeni sp. }\end{array}$ \\
\hline
\end{tabular}

Berdasarkan Tabel 10 tercatat ada 9 famili yaitu famili Caesionidae, Carangidae, Epipididhae, Labridae, Luthjanidae, Mullidae, Serranidea, Siganidae dan Spyraenidae serta tercatat 14 genus dan 28 spesies, menunjukkan kelompok ikan target masih banyak terdapat di lokasi penelitian. Jumlah famili yang mendominasi dari kelompok ikan target yaitu famili Caesionidae.

\section{Kondisi Lamun}

Berdasarkan pengamatan di Perairan Pantai Waha, lamun yang ditemukan pada lokasi penelitian sebanyak 9 jenis lamun yaitu : Halodule pinifolia, Halophila ovalis, Thalassodendron ciliatum, Halodule universis, Thalassia hempricii, Enhalus acoroides, Chymodocea serrulata, Chymodocea rotundata, Sryngodium isoetifolium. Kepadatan ratarata lamun setiap jenis di 3 titik pengamatan disajikan pada Gambar 5. 


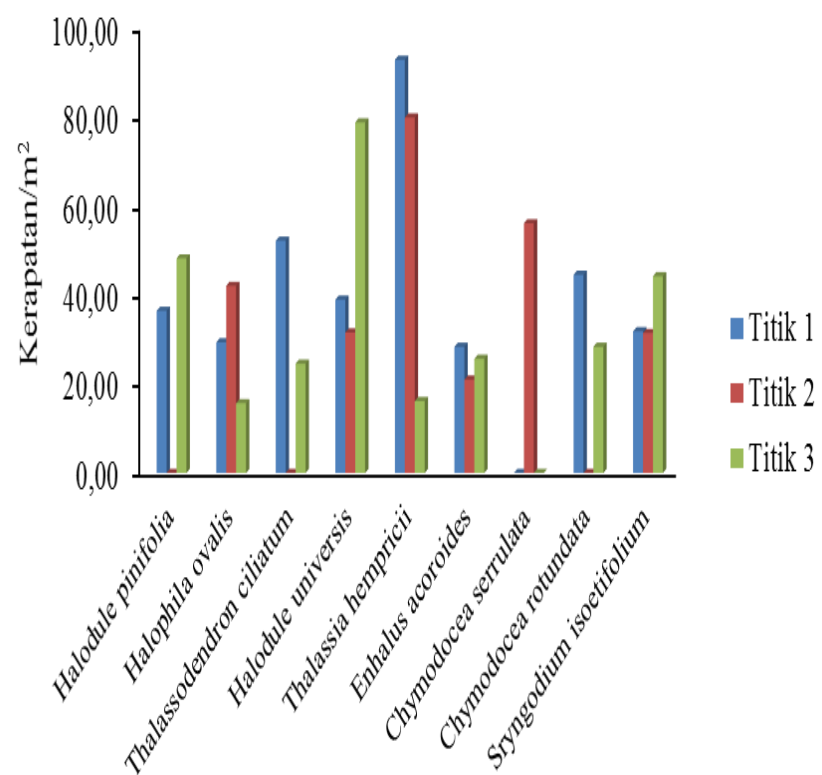

Gambar 5. Kerapatan setiap jenis lamun di DPL Desa Waha

Hasil analisis data kerapatan lamun DPL Desa Waha, menunjukan nilai rata-rata kerapatan yaitu 299,87 tegakan $/ \mathrm{m}^{2}$, dimana total kerapatan komunitas lamun pada titik pengamatan I lebih besar $(355,10$ tegakan $\left./ \mathrm{m}^{2}\right)$, dibandingkan titik pengamatan II $(262,4$ tegakan $\left./ \mathrm{m}^{2}\right)$ dan titik pengamatan III $(282,10$ tegakan $/ \mathrm{m}^{2}$ ). Setelah menilai kerapatan tegakan lamun kemudian menghitung kondisi persentase tutupan lamun di DPL Desa Waha berdasarkan luas tutupan pada transek. Nilai rata-rata presentasi lamun yaitu $63,25 \%$, termaksud dalam kategori baik.

\section{Efektivitas DPL}

Penentuan indikator efektivitas terpilih didapatkan berdasarkan analisis stakeholder, yakni indikatorindikator efektivitas yang ada pada IUCN (International Union for Conservation of Nature) dalam Pomeroy et al. (2004) dipilih oleh stakeholder dan dianggap indikator yang menggambarkan efektivitas pengelolaan DPL Desa Waha.

Tabel 4. Indikator efektivitas terpilih beserta nilai CTV dan dampaknya

\begin{tabular}{ccccc}
\hline \multirow{2}{*}{ Kriteria } & Indikator & Unit & CT & Kondi \\
& Terpilih & & si & DPL \\
& & & &
\end{tabular}

$\begin{array}{lllll}\text { Ekologi } & \begin{array}{l}\text { a. } \\ \text { Kondisi } \\ \text { Tutupan } \\ \text { Terumbu }\end{array} & \% & >25 & 55,83\end{array}$

\begin{tabular}{|c|c|c|c|c|}
\hline & Karang & & & \\
\hline & b. Kondisi & & & \\
\hline & Tutupan & $\%$ & $>25$ & 63,25 \\
\hline & Lamun & & & \\
\hline & $\begin{array}{l}\text { c. Kelimpah } \\
\text { an Ikan }\end{array}$ & Ind & $>25$ & 28 \\
\hline & Target & & & \\
\hline & d. Sikap & & & \\
\hline & $\begin{array}{l}\text { Masyarak } \\
\text { at }\end{array}$ & $\%$ & $>25$ & 100 \\
\hline & e. Presepsi & & & \\
\hline Sosial & Masyarak & $\%$ & $>25$ & 100 \\
\hline Ekonomi & at & & & \\
\hline & f. Partisipas & & & \\
\hline & $\begin{array}{l}\text { i } \\
\text { Masyarak }\end{array}$ & $\%$ & $>25$ & 100 \\
\hline & at & & & \\
\hline & g. Tingkat & & & \\
\hline & Partisipas & & & \\
\hline & $\mathrm{i}$ & $\%$ & $>25$ & 60 \\
\hline Kelembaga & $\begin{array}{l}\text { Stakehold } \\
\text { er }\end{array}$ & & & \\
\hline & h. Jumlah & & & \\
\hline & $\begin{array}{l}\text { Pelatihan } \\
\text { Stakehold } \\
\text { er }\end{array}$ & $\begin{array}{c}\text { Jumlah/t } \\
\text { hn }\end{array}$ & 1 & 5 \\
\hline
\end{tabular}

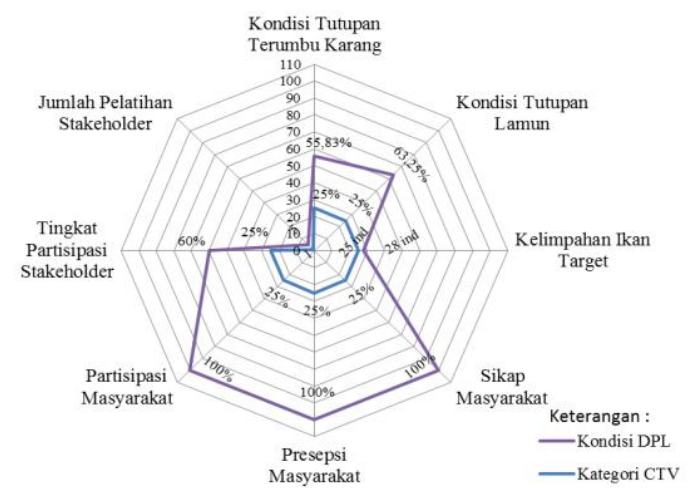

Gambar 6. Hasil analisis efektivitas pengelolaan DPL Desa Waha menggunakan teknik amoeba

Kriteria indikator efektivitas ini dibagi dalam 3 (tiga) kelompok, yaitu ekologi (kondisi tutupan karang, kerapatan lamun dan kelimpahan ikan target), kriteria sosial-ekonomi (pendapatan, sikap, presepsi dan partisipasi masyarakat), serta kelembagaan (jumlah pelatihan stakeholder). Indikator tersebut ditentukan batas kritisnya (Critical Threshold Value/CTV) dan dipadukan menggunakan grafik 
84 Ishak Iskandar et al.

JURNAL SAINS dan INOVASI PERIKANAN / Journal of Fishery Science and Innovation

Vol. 2, No. 2, 76-86, Juli 2018

Amoeba (Brink Ten et al. 1991; Ridaura et al. 2002; Glaser 2003). Penilaian dampak dilihat dengan membandingkan kondisi ekologi, sosial-ekonomi dan kelembagaan saat ini dan dengan nilai batas kritis (Critical Threshold Value/CTV). Pengelompokkan indikator efektivitas terpilih beserta nilai kritis dan dampaknya pada Tabel 4 .

\section{Analisis Efektivitas}

Analisis efektivitas penetapan dan pengelolaan DPL Desa Waha ditampilkan dengan menggunakan teknik amoeba dalam bentuk diagram pada Gambar 6 .

Tabel 6. Matriks Tingkat Efektivitas

\begin{tabular}{|c|c|c|c|c|c|c|c|}
\hline \multirow{2}{*}{ Kriteria } & \multirow{2}{*}{ Indikator Terpilih } & \multirow{2}{*}{ Bobot } & \multirow{2}{*}{ Skor Real } & \multicolumn{4}{|c|}{ Kriteria Skor } \\
\hline & & & & 0 & 1 & 2 & 3 \\
\hline \multirow{3}{*}{ Ekologi } & a. Kondisi Tutupan Karang & 3 & 2 & $0-25$ & $>25-50$ & $>50-75$ & $>75-100$ \\
\hline & b. Kondisi Kepadatan Lamun & 3 & 2 & $0-25$ & $>25-50$ & $>50-75$ & $>75-100$ \\
\hline & c. Kelimpahan Ikan Target & 3 & 1 & $0-25$ & $>25-50$ & $>50-75$ & $>75$ \\
\hline \multirow{3}{*}{$\begin{array}{l}\text { Sosial } \\
\text { Ekonomi }\end{array}$} & d. Sikap Masyarakat & 3 & 3 & $0-25$ & $>25-50$ & $>50-75$ & $>75-100$ \\
\hline & e. Presepsi Masyarakat & 3 & 3 & $0-25$ & $>25-50$ & $>50-75$ & $>75-100$ \\
\hline & f. Partisipasi Masyarakat & 3 & 3 & $0-25$ & $>25-50$ & $>50-75$ & $>75-100$ \\
\hline \multirow{5}{*}{ Kelembagaan } & g. Tingkat Partisipasi Stakeholder & 3 & 2 & $0-25$ & $>25-50$ & $>50-75$ & $>75-100$ \\
\hline & h. Jumlah Pelatihan Stakeholder & 3 & 3 & 0 & 1 & 2 & $>2$ \\
\hline & Skor Efektivitas & \multicolumn{6}{|c|}{19} \\
\hline & Skor Total & \multicolumn{6}{|c|}{24} \\
\hline & Tingkat Efektivitas & \multicolumn{6}{|c|}{$79,17 \%$} \\
\hline
\end{tabular}

Hasil analisis yang dicapai dalam pengelolaan DPL Desa Waha diketahui melalui pengukuran pada beberapa indikator ekologi,

sosial ekonomi dan kelembagaan dengan membandingkan data kategori CTV dan kondisi saat ini.

Berdasarkan analisis efektivitas menggunakan teknik Amoeba, nilai-nilai indikator secara umum terlihat keragaan (performance) indikator lebih baik dibandingkan dengan indikator CTV. Hal ini dikarenakan nilai-nilai tersebut belum melewati nilai ambang batas kritis (CTV).

\section{Tingkat Efektivitas Pengelolaan DPL}

Analisis perhitungan tingkat efektivitas DPL Desa Waha dalam penelitian ini dapat dilihat pada Tabel 6.

Analisis tingkat efektivitas DPL Desa Waha dalam penelitian ini dilakukan untuk mengukur tingkat efektivitas pengelolaan DPL saat ini dan didasarkan pada indikator-indikator terpilih yang ditetapkan tingkatannya (indeks). Hasil analisis tingkat efektivitas pengelolaan DPL Desa Waha tersaji pada Tabel 6 .
Berdasarkan hasil perhitungan tingkat efektivitas pengelolaan DPL Desa Waha berada pada tingkat $79,17 \%$ dan dikategorikan sangat efektif. Menurut Carter et al. (2011), skor dan tingkat yang dicapai melalui setiap tinjauan tidak ditujukan untuk menentukan status "pasti" dari efektivitas pengelolaan, tetapi untuk lebih mencerminkan tingkat pencapaian relatif terhadap tujuan akhir dan tujuantujuan yang digunakan untuk pengembangan dan pengelolaan kawasan tersebut pada masa yang akan datang. Selain itu, Carter et al. (2001) menyebutkan bahwa pada tingkatan tersebut merupakan tingkat tertinggi dari efektivitas pengelolaan kawasan perlindungan laut. Pada tingkatan ini menunjukkan bahwa kawasan perlindungan laut tersebut telah dikelola dengan kelembagaan yang berfungsi penuh. Hal ini dikarenakan DPL Desa Waha sudah berjalan lebih dari 10 tahun, sehingga telah melalui beberapa tahapan pengelolaan, yaitu (1) pengelolaan bagi kawasan perlindungan yang baru berjalan, (2) dikelola secara minimum, (3) dikelola dengan penegakan aturan dan (4) dikelola secara berkelanjutan, sehingga mencapai tingkatan tersebut. Dengan demikian, pengelolaan DPL Desa Waha yang telah dianalisis dan berada pada kategori sangat layak pada penelitian 
ini diharapkan akan meningkatkan pelestarian keanekaragaman hayati laut dan pada gilirannya dapat memperkuat layanan ekosistem yang bermanfaat untuk mendukung pembangunan berkelanjutan masyarakat setempat dan pembangunan daerah Kabupaten Wakatobi.

\section{KESIMPULAN}

Kesimpulan penelitian ini adalah : 1) Kondisi ekologi yang terdiri dari tutupan karang, kelimpahan ikan dan tutupan lamun di Perairan Daerah Perlindungan Laut Desa Waha berada dalam kondisi "baik" dengan nilai masing-masing untuk tutupan karang 55,83\%, untuk kelimpahan ikan karang ditemukan ikan target sebanyak 28 spesies, dan tutupan lamun sebesar $63,25 \%$. 2) Nilai indikator sosial dan kelembagaan dengan menilai persepsi, sikap, partisipasi masyarakat dan stakeholder serta jumlah pelatihan yang diikuti stakeholder semuanya menunjukkan nilai yang maksimal dan berada di atas nilai CTV.3) Tingkat Efektivitas Daerah Perlindungan Laut Desa Waha dengan menilai semua indikator menunjukkan hasil yang 'sangat efektif' dengan nilai tingkat efektivitasnya yaitu $79,17 \%$.

\section{DAFTAR PUSTAKA}

Alwin, 2017. Evaluasi Daerah Perlindungan Laut Terhadap Kondisi Sumber Daya dan Lingkungan Pesisir Desa Waha Kec.WangiWangi. Skripsi Perikanan dan Kelautan. Fakultas Universitas Halu Oleo. Kendari.

Ayiful, R.A. 2004. Strategi Pengembangan Kegiatan Pariwisata Di Taman Nasional Kepulauan Wakatobi Sulawesi Tenggara. Tugas Akhir, Jurusan Perencanaan Wilayah dan Kota. FTUNDIP. Semarang.

Balai Taman Nasional Baluran, 2010. Laporan Pengumpulan Data dan Identifikasi Ikan Karang Di Pantai Bama Sebagai Data Dasar Ikan Karang Taman Nasional Baluran Di Pantai Bama dan Kalitopo.http://Balurannationalpark.Web. Id/ Wp- Content/ Uploads/201 1/03/2010Ikankarang-02 07april2010-Done.pdf. Di Akses Pada Hari Minggu, 01 Mei 2011. 08:16:00 PM. 57 hal.
BPS Kabupaten Wakatobi, 2017. Kabupaten Wakatobi Dalam Angka. Badan Pusat Statistik Kabupaten Wakatobi. Provinsi Sulawesi Tenggara.

Brink Ten, B.J.E., Hosper, S.H., Colin, F. 1991. A quantitative method for description and assessment of ecosystems: the AMOEBAapproach. Mar Pollut Bull 23: 265-270.

Brower, J.E., Zar, J.H, Von Ende. 1990. General Ekology, Field and Labaoratory Methods for General Ecology. Ed Ke-3. Iowa: America W M. C. Brow Company Publisher Dubugue.

Carter, E., A. Soemodinoto, A. White. 2011. Panduan untuk Meningkatkan Efektivitas Pengelolaan Kawasan Konservasi Laut di Indonesia. BaliIndonesia: Program Kelautan The Nature Conservancy Indonesia.

Carter, J.A. 1996. Introductory Couse on Integrated Coastal Zone Management(Tarining Manual). Pusat Penelitian Sumberdaya Alam dan Lingkungan Sumatra Utara, Medan, dan Pusat Penelitian Sumberdaya Manusia dan LingkunganUniversitas Indonesia, Jakarta; Dalhousle University, Enviromental Studies Centre Development in Indonesia Project.

Coremap. 2006. Modul Biota Asosiasi dan Pola Interaksi Antar Spesies. Disampaikan pada Pelatihan Ekologi Terumbu Karang. Banteng Selayar: Yayasan Lanra Link Makassar. Coremap Fase II. Tanggal 22-26 Juli.

Coremap II Coral Reef Rehabilitation and Management Program Phase II. 2006. Daerah Perlindungan Laut Berbasis Masyarakat. Vol. 2. Dir. Jend. Kelautan Pesisir dan Pulau-Pulau Kecil. Departemen Kelautan dan Perikanan. Jakarta.

Coremap II Kabupaten Wakatobi. 2011. Kondisi Kesehatan Terumbu Karang (Laporan Kegiatan).

Faiza, R. 2011. Efektivitas dan Keberlanjutan Pengelolaan Daerah Perlindungan Laut Berbasis Masyarakat. Disertasi. Sekolah Pasca Sarjana IPB. Bogor.

Glaser, M. 2003. Interrelations between Mangrove Ecosystems, Local Economy and Social Sustainability in the Caete Estuary. North Brazil. Wetl Ecol Manag 11: 265-272.

Gomez, E.D, Yap, H.T. 1984. Monitoring Reef Condition. In : Kenchington RA and Hudson BET (editors). Coral Reef Management Handbook. 2nd edition. Jakarta: UNESCO 
86 Ishak Iskandar et al.

JURNAL SAINS dan INOVASI PERIKANAN / Journal of Fishery Science and Innovation Vol. 2, No. 2, 76-86, Juli 2018

Regional Office for Science and Technology for South East Asia.

Manuputty, A.E.W, Djuwariah. 2009. Panduan Metode Point Intercept Transect (PIT) Untuk Masyarakat. COREMAP II-LIPI. Jakarta.

Pollnac, R., L. Bunce, P. Townsley, Robert, P. 2000. Socioeconomic Manual For Coral Reef Management. Global Coral Reef Monitoring Network (GCRMN).

Pomeroy, R.S., Parks, J.E., Watson, L.N. 2004. How Is Your MPA Doing? A Guide book of Natural and Sosial Indicators For Marine Protected Area Management Effectiveness. IUCN-The Word Conservation Union.

Ridaura, S.L, O. Masera, M. Astier. 2002. Evaluating the Sustainability of Complex SocioEnvironmental Systems the MESMIS Framework. Ecol Indic 2: 135-148.

Subhan. 2009. Monitoring Kondisi Terumbu Karang di DPL Program COREMAP II Wakatobi. 74 hal.

Supriatna, J. 2008. Melestarikan Alam Indonesia. Yayasan Obor Indonesia. Jakarta. 